\title{
EVALUATING THE POSSIBILITY OF RECYCLING BANANA WASTE AS A FEED FOR RUMINANTS: \\ II- GROWTH PERFORMANCE, BLOOD PICTURE, AND FEEDING ECONOMICS BY LAMBS

\author{
Abdelhamid, A. M.*; G. H. A. Ghanem**; A. M. Aiad ${ }^{\star *}$ and \\ R. I. M. Matari** \\ ${ }^{*}$ Faculty of Agriculture, Al-Mansourah University \\ ** Animal Production Res. Institute, Agric. Res. Center, Egypt.
}

\begin{abstract}
Three underground trenches with the capacity of 6 tons (2 tons each) were used for making silage from banana wastes. Rice straw was added to banana wastes at the rate of $1: 2$, while molasses was added at the rate of $5 \%$. The first silage $\left(T_{2}\right)$ was made without any additive. In the second silage $\left(\mathrm{T}_{3}\right)$, urea was added at the rate of $3 \%$, while in the third silage $\left(\mathrm{T}_{4}\right), \mathrm{EM}_{1}$ (biological treatment) was added at the rate of $1 \%$. Whereas $\mathrm{T}_{1}$ was a control. The rations were ad libitum of silage, while concentrate feed mixture consisted $70 \%$ from the requirements. Twenty lambs (cross breed Finnish rams, Finnish $\times$ Rahmani) having 4 months of age and averaging $22 \pm$ $0.5 \mathrm{Kg}$ live body weight were used in this experiment. Lambs were divided into four similar groups according to their live body weight (5 animals in each). The results indicated significant $(P<0.05)$ differences in daily bodyweight gain between $\left(T_{2}\right.$ and $\left.T_{4}\right)$ and $\left(T_{1}\right.$ and $\left.T_{2}\right)$, being (111.94 and 145.37$)$ and (164.72 and $\left.111.94 \mathrm{~g} / \mathrm{h} / \mathrm{d}\right)$, respectively; yet, insignificant $(P>0.05)$ differences were found between $\left(T_{3}\right.$ and $\left.T_{4}\right)$ and $\left(T_{2}\right.$ and $\left.T_{3}\right)$, being (131.11 and 145.37$)$ and $(111.94$ and $131.11 \mathrm{~g} / \mathrm{h} / \mathrm{d})$, respectively. The $T_{4}$ showed more feed intake compared to $T_{3}$ and $T_{2}$, being 189.45 , 183.87 and $174.29 \mathrm{~kg}$, respectively, and significant $(P<0.05)$ differences were found between ( $T_{2}$ and $\left.T_{4}\right)$ and ( $T_{1}$ and $T_{2}$ ), being (174.29 and 189.45) and 199.94 and $174.29 \mathrm{~kg})$, respectively, but insignificant $(P<0.05)$ differences were found between ( $T_{2}$ and $\left.T_{3}\right)$ and ( $T_{3}$ and $T_{4}$ ), being (174.29 and 183.87) and (183.87 and $189.45 \mathrm{~kg}$ ), respectively. Concerning feed conversion, there were no significant differences among $T_{1}, T_{3}$ and $T_{4}$ and among $T_{2}, T_{3}$ and $T_{4}$, being 6.8, 7.87 \& 7.33 and 8.78, 7.87 \& 7.33, respectively, but significant difference $(P<0.05)$ was found between $T_{1}$ and $\mathrm{T}_{2}$, being 6.8 and 8.78, respectively. Blood analysis showed no significant differences among treatments in red blood corpuscles count; yet, there were significant differences in hemoglobin, hematocrit value (\%), and white blood cells count among treatments. Moreover, no significant differences were recorded among treatments in globulin, A/G ration, AST, ALT urea nitrogen and creatinine. But significant differences $(P<0.05)$ were given among treatments in total protein, albumin and Alk$\mathrm{P}$-ase. Economic evaluation reflected significant differences $(\mathrm{P}<0.05)$ between $\mathrm{T}_{1}$ and $\mathrm{T}_{2}(216$ and $201 \%), \mathrm{T}_{1}$ and $\mathrm{T}_{4}(216$ and $239 \%), \mathrm{T}_{2}$ and $\mathrm{T}_{3}(201$ and $222 \%)$ and $\mathrm{T}_{3}$ and $\mathrm{T}_{4}(222$ and $239 \%)$. From the foregoing results it could be concluded that $\mathrm{EM}_{1}$ as an additive for making silage of banana waste was effective and costly from the view point of economy, even concerning feed conversion which was statistically similar to the control. So, it to recommend using banana waste silage with $\mathrm{EM}_{1}$ (or urea) in feeding ruminants without any harm effects on growth performance, feed utilization and animal health, but to overcome, to some extent, the gap in animal feed stuffs by introducing banana waste silage as a novel feed resource in the economical animal production.
\end{abstract}

Keywords: Banana waste - Lambs - Performance - Blood - Economics. 


\section{INTRODUCTION}

In Egypt, animal feed resources are limited which do not allow increasing livestock population to a level satisfies human demands. Moreover, feed shortage is also unevenly divided between summer and winter. Encouraging results obtained confirm that using crops wastes in animal diets could participate in reducing the shortages of animal feeds and subsequently increase milk and meat production. Many efforts have been done to evaluate available waste products for feeding animals (Abdelhamid, 1988). Banana leaves and pseudo stems have chemical analysis close to clover composition and can play an important role to cover some nutrient requirements of the animals (Abd El-Gawad et al., 1994). Highest live weight gain was achieved when diet was supplemented with banana, this suggests that fodder supplement with green banana can improve cattle nutrition in the humid tropics (Ibrahim et al., 2000). Wastes of banana trees are one of the solutions may share in solving this problem. Biological treatments (El-Ashry et al., 2003 and Abdelhamid et al., 2006, 2007, 2009a, b and c) were used to improve the nutritive value and digestibility of poor quality roughages. Increasing the digestibility of the diet by using exogenous enzymes will lead to the beneficial effects on animal performance, so such treatments are likely to be greatest for ruminants in negative energy balance, such as animals in early lactation (Rode et al., 1999). The main objective of this study was to determine the influence of incorporation of different kinds of silage made from banana plant wastes on growth performance, feed intake and conversion and same blood parameters besides economic efficiency by ram lambs.

\section{MATERIALS AND METHODS}

This work was carried out at Sakha Animal Production Station, Animal Production Research Institute, Agric. Research Center and Animal Production Department, Faculty of Agriculture, Al-Mansourah University during 2007/2008 for about 26 weeks. Silage preparation, diets and animals used herein are the same mentioned in the $1^{\text {st }}$ part of this series (Abdelhamid et al., 2009d). So, to study the effect of feeding lambs on three different types of silage on growth performance, twenty crossbred ram lambs (3/8 Finnish Landrace x 5/8 Rahmani) having 4-5 months of age and averaging $22 \pm 0.5$ $\mathrm{Kg}$ live body weight were used in this experiment. Lambs were divided into four similar groups according to their live body weight (5 animals in each). Lambs in all groups were fed diets which contained the same amount of concentrate feed mixture (CFM). The dietary treatments were T1) concentrate feed mixture (CFM) of lactation $(17 \% \mathrm{CP})+$ berseem hay $(\mathrm{BH})$ as a control; T2) CFM + banana waste silage (BWS) without additives (banana waste $2: 1$ rice straw $+5 \%$ molasses); T3) CFM + BWS with urea $3 \%$ $+5 \%$ molasses (BWUS); and T4) CFM + BWS with effective microorganisms $1 \%\left(\mathrm{EM}_{1}+5 \%\right.$ molasses, BWES). Feeding of all groups was on the basis of $4 \%$ DM of their live body weight, concentrate ratio in diet of all groups was $70 \%$ from NRC (1985) requirement silage ad libitium. Amount of CFM were 
adjusted biweekly according to the actual live body weight. The experimental feeding period lasted from weaning up to 180 days. Freshwater and Calphos Block (from Turkey) were available all times and feeds were offered twice daily at 8 a.m and 4 p.m.

Throughout the feeding period of lambs, all animals were biweekly weighed and average daily gain was calculated. At the end of each digestibility trial, blood samples were collected from each animal at early morning before feeding from the jugular vein of each animal at 8 a.m into vacationer tubes. Hematological parameters: including count of red blood cells (RBC's) and white blood cells (WBC's), packed cell volume (PCV\%), and hemoglobin concentration were determined in fresh whole blood using fully digital hematology counter (Laboratories, USA). Other collected samples were allowed to clot and centrifuged at $3500 \mathrm{rpm}$ for 20 minutes to separate blood serum. Serum was carefully decanted into labeled tubes using serological pipettes and stored at $-20^{\circ} \mathrm{C}$ until analysis. Total protein and albumin concentrations were determined using commercial kits according to the Douman et al. (1971). Globulin was calculated by difference. Albumin/globulin ratio was calculated. Activities of serum transaminases AST and ALT were determined according to Reitman and Frankel (1957), whereas serum activity of alkaline phosphatase was determined by the method of King and King (1959). Blood serum was tested for urea nitrogen concentration according to Talke and Schubert (1965) and for creatinine by the method of Joffe reaction described by Giorgio (1974). All biochemical parameters were estimated using colorimetric methods via commercial kits purchased from bio-Merieux, Laboratory Reogents and Products, France.

Economical efficiency was determined according to price of 1 ton of concentrate feed mixture $(\mathrm{FCM})=1500 \mathrm{LE}$, price of 1 ton of berseem hay $=$ $700 \mathrm{LE}$, price of 1 ton of banana waste silage $=110 \mathrm{LE}$, silage with urea $=$ $130 \mathrm{LE}$, price of 1 ton of Banana waste silage with $\mathrm{EM}_{1}=110 \mathrm{LE}$, market price of $1 \mathrm{Kg}$ live body weight year $2008=18 \mathrm{LE}$, total feed cost = intake of different feed stuffs $x$ their prices, feed cost $/ \mathrm{Kg}$ gain $=$ total feed cost/total weight gain, output of total weight gain = total weight gain $x$ price of $1 \mathrm{Kg}$ live body weight, and economic efficiency $=$ (output of total weight gain/total feed cost) $X 100$.

Statistical analysis:

The obtained data were statistically analyzed using general linear models procedure adapted by SPSS (2004) for Windows for user's guide. Least significant differed according to Duncan (1955) within program SPSS was done to determine the degree of significance between means.

\section{RESULTS AND DISCUSSION}

\section{Growth performance:}

Body weight and gain:

Results in Table (1) show that lambs in the control group $\left(\mathbf{T}_{1}\right)$ showed the highest significantly $(P \leq 0.05)$ final weight and total and daily gain as compared to those fed banana waste in fresh $\left(\mathrm{T}_{2}\right)$, silage with urea 
$\left(T_{3}\right)$ or silage with EM1 $\left(T_{4}\right)$. In comparing different banana waste groups, lambs in $\mathrm{T}_{4}$ (fed banana waste with EM1) showed the highest growth performance parameters, being significantly $(P \leq 0.05)$ higher than those in $T_{2}$ (fresh banana waste), but did not differ significantly ( $P \geq 0.05)$ from those in $\mathrm{T}_{3}$ (banana waste silage with urea). Viswanathan et al. (1989) studied the effect of the nutritive value of banana stalks which replaced $0,20,40$ and $50 \%$ of paragrass. Feeding banana stalks did not have any detrimental effect on the health of the sheep and that although the daily live-weight gains were low, the rate increased up to $40 \%$ level of inclusion after which it started to decline. However, Abdelhamid et al. (1991a) found that urea treated (ensiled) rice straw reflected non significant $(P>0.05)$ decrease of cows body weight gain. On the other side, Abdelhamid et al. (1991b) reported insignificant $(P>$ $0.05)$ higher body weight and daily body gain rate of calves fed urea supplemented rice straw. Yet, the biological treatment with white rat fungi improved live body weight and growth rate of lambs (Abdelhamid et al., 2009c)

\section{Feed and nutrients intake:}

It could be seen from Table (1) that total dry matter feed intake averaged 199.94, $174.29,183.87$ and $189.45 \mathrm{Kg}$ for growing lambs fed on $\mathrm{T}_{1}$ $(\mathrm{CFM}+\mathrm{BH}), \mathrm{T}_{2}(\mathrm{CFM}+\mathrm{BWS}), \mathrm{T}_{3}(\mathrm{CFM}+\mathrm{BWUS})$ and $\mathrm{T}_{4}(\mathrm{CFM}+\mathrm{BWES})$, respectively during the whole period of 26 weeks. These results indicated that the $T_{4}$ showed more feed intake compared to $T_{3}$ and $T_{2}$. There were significant $(P<0.05)$ differences between $T_{2} \& T_{4}$ and $T_{1} \& T_{2}$ (being 174.29 vs. 189.45 and 199.94 vs. 174.29 , respectively) and insignificant differences between $T_{2} \& T_{3}$ and $T_{3} \& T_{4}$ (being 174.29 vs. 183.87 and 183.87 vs. 189.45, respectively). Data in Table (1) indicate that the $T_{4}$ showed more TDN intake compared to $T_{3}$ and $T_{2}$, being $123.10,116.37$ and $104.76 \mathrm{Kg}$, respectively. There was no significant difference $(P>0.05)$ between $T_{3}$ and $T_{4}(116.37$ and $123.10 \mathrm{Kg})$. Yet, there were significant differences $(P<0.05)$ among $T_{1}, T_{2}$, $\mathrm{T}_{3}$ and $\mathrm{T}_{4}(135.5,104.76,116.37$ and $123.10 \mathrm{Kg}$, respectively). Also, the results indicated that the $T_{4}$ and $T_{3}$ showed more DCP intake compared to $T_{2}$ (19.29, 19.23 and $16.59 \mathrm{Kg}$, respectively). Significant differences $(P<0.05)$ were found between $T_{2}$ and each of $T_{3}$ and $T_{4}(16.59,19.23$ and $19.29 \mathrm{Kg}$, respectively). Also significant differences were found between $T_{1}$ and other treatments (22.29, $16.59,19.23$ and $19.29 \mathrm{Kg}$, respectively). There was no significant difference between $\mathrm{T}_{3}$ and $\mathrm{T}_{4}(19.23$ and $19.29 \mathrm{Kg}$, respectively. The obtained results agree with those of Gerona et al. (1986), who compared the DM intake of cattle and carabao fed solely on leaves, pseudo stem or corm. The carabao generally had a higher DM intake than cattle of both pseudo stem and leaves, but on a live weight basis the DM intake was slightly lower in carabao than in cattle. Viswanathan et al. (1989) found that the dry matter intake per $\mathrm{Kg} \mathrm{W}^{0.75}$ was fairly similar in all treatments. Yet, Geaffroy et al. (1978) compared the DM intake of banana leaves and stem with pangola grass by Alpine goats. Dry matter intake $(\mathrm{Kg} / 100 \mathrm{Kg}$ body weight) was 1.36 from banana leaves, 0.66 from stems and 2.26 from pangola grass. Kholif et al. (2001) found that dry matter intake slightly $(\mathrm{P}>$ 0.05 ) increased with $T_{2}$ (Penicillium funiculusma) and $T_{3}$ (Saccharomyces cerevi) compared with control. Hassan et al. (2005) found that treatment of 
banana waste silage resulted in increasing roughage intake, especially with inoculate and $\mathrm{EM}_{1}$ treatment. Recently, Abdelhamid et al. (2007) mentioned that fungal treatment led to low DM intake and feed efficiency by lambs.

Table (1): Growth performance of growing lambs fed the experimental diets (means $\pm \mathrm{SE}$ ).

\begin{tabular}{|c|c|c|c|c|}
\hline \multirow{2}{*}{ Item } & \multicolumn{4}{|c|}{ Experimental treatments } \\
\hline & $T_{1}$ & $T_{2}$ & $T_{3}$ & $\mathbf{T}_{4}$ \\
\hline No. of animals & 5 & 5 & 5 & 5 \\
\hline Initial body weight (Kg) & $22.20 \pm 0.73$ & $22.20 \pm 0.86$ & $22.20 \pm 0.58$ & $22.40 \pm 0.68$ \\
\hline Final body weight $(\mathrm{Kg})$ & $51.85+1.28^{a}$ & $42.35+1.50^{c}$ & $45.85 \pm 0.65^{b c}$ & $48.17+1.20^{\mathrm{ab}}$ \\
\hline Total gain $(\mathrm{Kg})$ & $29.65 \pm 1.41^{\mathrm{a}}$ & $20.15 \pm 1.41^{\mathrm{c}}$ & $23.60 \pm 1.31^{b c}$ & $26.17 \pm 2.19^{\mathrm{ab}}$ \\
\hline Average daily gain $(\mathrm{g})$ & $164.94 \pm 7.86^{a}$ & $111.94 \pm 7.86^{c}$ & $131.11 \pm 7.31^{b c}$ & $145.37 \pm 12.14^{\mathrm{ab}}$ \\
\hline \multicolumn{5}{|c|}{ Feed intake and nutritive values on DM basis (Kg): } \\
\hline Concentrate & 133.29 & 116.19 & 122.58 & 126.30 \\
\hline Berseem hay & 66.65 & - & - & - \\
\hline Silage & - & 58.10 & 61.29 & 63.15 \\
\hline Total feed intake & $199.94 \pm 4.15^{\mathrm{a}}$ & $174.29 \pm 5.37^{c}$ & $183.87 \pm 1.29^{\mathrm{bc}}$ & $189.45 \pm 0.90^{\mathrm{ab}}$ \\
\hline TDN & $135.50 \pm 2.81^{\mathrm{a}}$ & $104.76 \pm 3.23^{c}$ & $116.37 \pm 0.82^{b}$ & $123.10 \pm 0.58^{b}$ \\
\hline DCP & $22.29 \pm 0.46^{a}$ & $16.59 \pm 0.51^{c}$ & $19.23 \pm 0.13^{b}$ & $19.29 \pm 0.09^{b}$ \\
\hline \multicolumn{5}{|c|}{ Feed conversion ratio: } \\
\hline $\mathrm{DM}(\mathrm{Kg})$ & $6.80 \pm 0.30^{b}$ & $8.78 \pm 0.53^{a}$ & $7.87 \pm 0.45^{\mathrm{ab}}$ & $7.33 \pm 0.55^{\mathrm{ab}}$ \\
\hline TDN (Kg) & $4.61 \pm 0.20^{c}$ & $5.28 \pm 0.32^{a}$ & $4.98 \pm 0.29^{\mathrm{ab}}$ & $4.76 \pm 0.36^{b c}$ \\
\hline $\mathrm{DCP}(\mathrm{g})$ & $757.71 \pm 33.27^{b}$ & $835.54 \pm 50.84^{a}$ & $822.80 \pm 47.41^{\mathrm{a}}$ & $746.38 \pm 55.88^{b}$ \\
\hline
\end{tabular}

a, $b$ and c: Means with different superscripts in the same row are significantly different at $(P<0.05)$.

\section{Feed conversion:}

It could be seen from Table (1) that the feed conversion $(\mathrm{Kg} \mathrm{DM} / \mathrm{Kg}$ gain) averaged 6.8 $T_{1}, 8.78 T_{2}, 7.87 T_{3}$ and 7.33 $T_{4}$. No significant differences were found among $T_{1}, T_{3}$ and $T_{4}$ and among $T_{2}, T_{3}$ and $T_{4}$, but there was significant difference between $T_{1}$ and $T_{2}$ (6.8 and 8.78, respectively). Feed conversion as ( $\mathrm{Kg}$ TDN/Kg gain) could be seen from Table (1). The results indicated that there were no significant differences between $T_{1}$ and $T_{4}$ and between $\mathrm{T}_{3}$ and $\mathrm{T}_{4}$ (4.61 and 4.76 and 4.98 and 4.76 , respectively). But there were significant $(P<0.05)$ differences between $T_{1} \& T_{2}$ and between $T_{1} \& T_{3}$ (4.61 \& 5.28 and $4.61 \& 4.98$, respectively). Data of feed conversion as ( $g$ $\mathrm{DCP} / \mathrm{Kg}$ gain) given in Table (1) show no significant $(\mathrm{P}>0.05)$ differences between $T_{1} \& T_{4}$ and $T_{2} \& T_{3}(757.71 \& 746.38$ and 835.54 \& 822.80, respectively). But significant $(P<0.05)$ differences were found between $T_{1} \&$ $T_{2}, T_{1} \& T_{3}$ and $T_{2} \& T_{4}$ (757.71 \& 835.54, 757.71 \& 822.80, and 835.54 \& 746.38, respectively). It was noticed that $\mathrm{T}_{4}$ resulted in the best feed conversion, whether as DM, TDN, or DCP/gain comparing with the both other treatments $\left(T_{3}\right.$ and $\left.T_{2}\right)$, followed by $T_{3}$ and at least $T_{2}$. Yet, the control was significantly $(P<0.05)$ equal to $T_{4}$. The superiority of feed conversion with $T_{4}$ is related to its superiority also in final body weight, total gain, and average daily gain (Table 1), in addition to its superiority in digestibility coefficients of $\mathrm{DM}, \mathrm{OM}, \mathrm{CF}, \mathrm{EE}$, and NFE as well as in the nutritive values (Abdelhamid et al., 2009d). This dependent also on its chemical composition (high CP and NFE, and its lower tannins content (Abdelhamid et al., 2009d). This is in agreement with Mashour et al. (2002), who reviewed the benefits of EM, 
which excrete analytical enzymes, acids, chelating agents, and antibiotics, so improves chemical composition, digestion and feeding value and consequentially also animal performance. Also, Shoukry et al. (1999) recommended to ensile banana wastes as animal feed either with or without urea addition to depress the ill effect of the presence of some anti-nutritional factors such as tannins and alkaloids. However, Kholif et al. (2001) found that feed efficiency was insignificantly $(P>0.05)$ improved with all biological treatments. Moreover, Bendary et al. (2006) refer to the improving effect of $\mathrm{EM}_{1}$ on digestibility, nutritive value and feed conversion. Additionally, Hassan et al. (2005) and Mohsen et al. (2006) reoffered to the positive effects of biological treatment of banana waste on rumen parameters, degradability, and feeding value.

\section{Blood parameters:}

\section{Hematological parameters:}

Data of some hematological parameters of the blood collected from animals fed the tested rations are presented in Table (2). There were no significant differences among treatments in red blood corpuscles count, although there were significant differences $(P<0.05)$ between $T_{1}$ and $T_{2}$ (10.67 and 8.93), $T_{2}$ and $T_{3}\left(8.93\right.$ and 11.48) and $T_{2}$ and $T_{4}(8.93$ and 10.74 $\mathrm{g} / \mathrm{dl})$, respectively in hemoglobin concentrations; significant differences $(\mathrm{P}<$ 0.05 ) between $T_{2}$ and $T_{4}(33.33$ and 40.00$)$, respectively in hematocrit value (\%); and also significant differences $(P<0.05)$ between $T_{1}$ and $T_{4}(11.17$ and 13.07), $T_{2}$ and $T_{4}$ (10.92 and 13.07), and $T_{3}$ and $T_{4}$ (11.67 and 13.07), respectively in white blood cells count $\left(\times 10^{3} / \mathrm{mm}^{3}\right)$.

Table (2): Mean values \pm SE of some hematological parameters recorded in growing lambs fed the experimental diets.

\begin{tabular}{|c|c|c|c|c|}
\hline \multirow[b]{2}{*}{ Item } & \multicolumn{4}{|c|}{ Experimental treatments } \\
\hline & $\mathbf{T}_{1}$ & $\mathbf{T}_{2}$ & $\mathbf{T}_{3}$ & $\mathbf{T}_{4}$ \\
\hline Hemoglobin $(\mathrm{g} / 100 \mathrm{~g})$ & $10.67+0.22^{b}$ & $8.93+0.13^{b}$ & $11.48+0.30^{\mathrm{a}}$ & $10.74+0.66^{a}$ \\
\hline Hematocrit value (\%) & $37.67 \pm 0.88^{\mathrm{ab}}$ & $33.33 \pm 2.60^{b}$ & $38.67 \pm 2.03^{a b}$ & $40.00 \pm 1.53^{a}$ \\
\hline Red blood corpuscles $\left(\times 10^{6} / \mathrm{mm}^{3}\right)$ & $8.47 \pm 0.52^{a}$ & $8.13 \pm 0.12^{a}$ & $9.53 \pm 0.92^{a}$ & $8.47 \pm 0.67^{a}$ \\
\hline White blood cells $\left(\times 10^{3} / \mathrm{mm}^{3}\right)$ & $11.17 \pm 0.13^{\mathrm{b}}$ & $10.92 \pm 0.14^{b}$ & $11.67 \pm 0.47^{b}$ & $13.07 \pm 0.20^{a}$ \\
\hline
\end{tabular}

\section{Biochemical parameters:}

Blood profile was completed by estimations of some biochemical parameters in the blood serum for animals fed the tested rations. Their data are presented in Table (3). There were no significant differences among treatment in concentrations of globulin, urea- $\mathrm{N}$ and creatinine, albumin/globulin ration, and activity of AST and ALT. Yet, there were significant differences $(P<0.05)$ among treatments in total protein, albumin, and Alk-P-ase. Total protein significantly differed between ( $T_{1}$ and $T_{3}$ ) and ( $\mathrm{T}_{3}$ and $\mathrm{T}_{4}$ ), being 7.23 and 8.97 and 8.97 and $7.43 \mathrm{~g} / \mathrm{dl}$, respectively. Also, albumin significantly differed between ( $T_{1}$ and $\left.T_{2}\right),\left(T_{1}\right.$ and $\left.T_{3}\right),\left(T_{2}\right.$ and $\left.T_{4}\right)$ and ( $T_{3}$ and $T_{4}$ ), being (3.97 and 5.13), (3.97 and 5.33), (5.13 and 4.20) and (5.33 and $4.20 \mathrm{~g} / \mathrm{dl}$ ), respectively. Alk-P-ase significantly differed between $T_{2} 80.83$ and $T_{4} 30.20 \mathrm{IU} / \mathrm{l}$. Mohamed (2001) showed that banana by-products treated 
with $4 \%$ urea revealed higher values for urea, AST and ALT but less values for globulin and the values for $\mathrm{Hb} \%$, total protein and albumin, were nearly similar to the untreated by-products before feeding. He reported also that banana by-products treated with bacteria plus fungi revealed higher values for $\mathrm{Hb} \%$, urea, AST and ALT but non significant differences in total protein, albumin and globulin compared to the untreated by-products before feeding. However, 3 hrs after feeding, higher values of total protein, globulin and urea but less values for AST and non significant values for $\mathrm{Hb} \%$, albumin and ALT were found compared to untreated banana by-products.

Table (3): Mean values \pm SE of some blood serum parameters recorded in growing lambs fed the experimental diets.

\begin{tabular}{|l|c|c|c|c|}
\hline \multirow{2}{*}{ Item } & \multicolumn{4}{|c|}{ Experimental treatments } \\
\cline { 2 - 5 } & $\mathbf{T}_{1}$ & $\mathbf{T}_{2}$ & $\mathbf{T}_{3}$ & $\mathbf{T}_{4}$ \\
\hline Total protein $(\mathrm{g} / \mathrm{dl})$ & $7.23 \pm 0.37^{\mathrm{b}}$ & $8.47 \pm 0.37^{\mathrm{ab}}$ & $8.97 \pm 0.44^{\mathrm{a}}$ & $7.43 \pm 0.32^{\mathrm{b}}$ \\
\hline Albumin $(\mathrm{g} / \mathrm{dl})$ & $3.97 \pm 0.14^{\mathrm{b}}$ & $5.13 \pm 0.34^{\mathrm{a}}$ & $5.33 \pm 0.23^{\mathrm{a}}$ & $4.20 \pm 0.29^{\mathrm{b}}$ \\
\hline Globulin $(\mathrm{g} / \mathrm{dl})$ & $3.27 \pm 0.30$ & $3.33 \pm 0.62$ & $3.63 \pm 0.26$ & $3.23 \pm 0.13$ \\
\hline A/G ratio & $1.23 \pm 0.11$ & $1.68 \pm 0.40$ & $1.48 \pm 0.08$ & $1.30 \pm 0.11$ \\
\hline Urea nitrogen $(\mathrm{mg} / \mathrm{dl})$ & $43.20 \pm 0.96$ & $43.07 \pm 2.24$ & $44.93 \pm 4.14$ & $44.67 \pm 2.62$ \\
\hline Creatinine $(\mathrm{mg} / \mathrm{dl})$ & $0.43 \pm 0.08$ & $0.51 \pm 0.05$ & $0.69 \pm 0.17$ & $0.61 \pm 0.16$ \\
\hline AST $(\mathrm{IU} / \mathrm{l})$ & $24.00 \pm 2.08$ & $25.00 \pm 1.15$ & $25.00 \pm 1.52$ & $24.33 \pm 1.76$ \\
\hline ALT $(\mathrm{IU} / \mathrm{l})$ & $10.33 \pm 2.40$ & $8.33 \pm 1.20$ & $7.00 \pm 1.00$ & $7.00 \pm 1.15$ \\
\hline Alk-P-ase (IU/l) & $54.40 \pm 18.50^{\mathrm{ab}}$ & $80.83 \pm 9.16^{\mathrm{a}}$ & $59.80 \pm 13.29^{\mathrm{ab}}$ & $30.20 \pm 4.76^{\mathrm{b}}$ \\
\hline
\end{tabular}

$a, b$ and $c$ : Means with different superscripts in the same row are significantly different at $(P<0.05)$.

Kholif et al. (2001) found that yeast treatment $\left(T_{3}\right)$ increased $(P<$ 0.01 ) serum total protein and albumin, while $\left(T_{2}, P\right.$. funiculusms) decreased $(P<0.01)$ serum AST and cholesterol compared with other treatments. Other blood parameters as globulin A/G ratio, urea, creatinine, ALT, Alk-Pase, glucose and lipids were not affected by treatments. On the other hand, Hassan et al. (2005) found no significant differences among groups concerning all blood constituent. Moreover, Mohsen et al. (2006) noticed no significant differences among groups concerning all blood parameters. Generally, the NPN inclusion or fungal treatment were associated with elevated blood contents of $\mathrm{Hb}, \mathrm{PCV}$, glucose, total protein and urea of the heifers without any ill symptoms (Abdelhamid et al., 1991a\&b and 2009b \& c). Also, feeding biologically treated roughages to lambs did not cause any abnormal conditions in liver and kidney functions, since all blood parameters reflected nearly similar values with no significant effect of the tested rations (Abdelhamid et al., 2007).

\section{Economic evaluation:}

The economic evaluation for the experimental diets of $\left(T_{1}, T_{2}, T_{3}\right.$ and $\left.T_{4}\right)$ is shown in Table (4). The present results showed significant $(P<0.05)$ differences among treatments in total feed cost, feed cost $/ \mathrm{Kg}$ gain, out put of total weight gain and economic efficiency. There were significant $(P<0.05)$ differences in economic efficiency between $\mathrm{T}_{1}$ and $\mathrm{T}_{2}$ (216 vs. 201\%), $\mathrm{T}_{1}$ and $\mathrm{T}_{4}$ (216 vs. $239 \%$ ), $\mathrm{T}_{2}$ and $\mathrm{T}_{3}\left(201\right.$ vs. $221 \%$ ) and $\mathrm{T}_{3}$ and $\mathrm{T}_{4}$ (221 vs. $239 \%$ ), respectively. The best economic efficiency was calculated for $\mathrm{T}_{4}$ which was even more economic than the control, as well as than the other treatments. 
In this results Abd El-Malik et al. (2003) and Mohsen et al. (2006) recommended that banana by product could be treated biologically (bacteria plus fungi) and chemically (\% urea) to minimize the cost of feeding ruminants. Also, El-Sherif et al. (2008) found that banana waste can be used with good growth performance and economic efficiency in complete diets alone or plus yeast culture. Recently, Abdelhamid et al. (2009 b \& c) reported that fungal treatment of agricultural by-products can offer unconventional animal feed which is economical and environmentally friend without any negative effects on animal health.

Table (4): Economic evaluation of the experimental rations fed to growing lambs (means $\pm \mathrm{SE}$ ).

\begin{tabular}{|l|c|c|c|c|}
\hline \multirow{2}{*}{ Item } & \multicolumn{4}{|c|}{ Experimental treatment } \\
\cline { 2 - 5 } & $\mathbf{T}_{1}$ & $\mathbf{T}_{2}$ & $\mathbf{T}_{3}$ & $\mathbf{T}_{4}$ \\
\hline Total feed cost, LE & $246.59 \pm 5.12^{\mathrm{a}}$ & $180.68 \pm 5.57^{\mathrm{c}}$ & $191.84 \pm 1.35^{\mathrm{bc}}$ & $196.71 \pm 0.93^{\mathrm{b}}$ \\
\hline Feed cost/Kg gain, LE & $8.38 \pm 0.37^{\mathrm{b}}$ & $9.10 \pm 0.55^{\mathrm{a}}$ & $8.21 \pm 0.47^{\mathrm{b}}$ & $7.61 \pm 0.57^{\mathrm{c}}$ \\
\hline Output of total weight gain, LE & $533.70 \pm 25.54^{\mathrm{a}}$ & $362.70 \pm 25.46^{\mathrm{c}}$ & $424.80 \pm 23.67^{\mathrm{bc}}$ & $471.00 \pm 39.34^{\mathrm{ab}}$ \\
\hline Economic efficiency, $\%$ & $216 \pm 0.09^{\mathrm{b}}$ & $201 \pm 0.12^{\mathrm{c}}$ & $221 \pm 0.13^{\mathrm{b}}$ & $239 \pm 0.19^{\mathrm{a}}$ \\
\hline
\end{tabular}

$a, b$ and $c:$ Means with different superscripts in the same row are significantly different at $(P<0.05)$.

CFM = 1500

Banana waste silage $=110 \quad$ Banana waste silage with urea $=130$

Banana waste silage with $E M_{1}=115$ [Local price of feed stuffs (LE/ton)].

From the foregoing results it could be concluded that $\mathrm{EM}_{1}$ as an additive for making silage of banana waste was effective and costly from the view point of economy, even concerning feed conversion which was statistically similar to the control. So, it to recommend using banana waste silage with $\mathrm{EM}_{1}$ (or urea) in feeding ruminants without any harm effects on growth performance, feed utilization and animal health, but to overcome, to some extent, the gap in animal feed stuffs by introducing banana waste silage as a novel feed resource in the economical animal production.

\section{REFERENCES}

Abd El-Gawad, A.M.; Abd El-Malik, W.H., Allam, Sabbah M. and EI-Said, I.M. (1994). Utilization of banana tomato and potato by-products by sheep. Egyptian J. Anim. Prod. Vol. 31, Supplement Issue. Nov.: 215.

Abd El-Malik, W.H.; Abd El-Gawad, A.M.; Shakweer, M.E. and Khalafalla, G.M. (2003). Improving banana wastes using chemical and biological treatments. Egypt. J. Nutr. And Feeds, 6(Special Issue): 1039-1053.

Abdelhamid, A. M. (1988). Utilization From Agro-industrial By-products in Ruminant's Feeding. $1^{\text {st }}$ Nat. Conf. on the Role of the Sci. Res. in Raising Animal Wealth. 2 ${ }^{\text {nd }}$ Forum: Developing Ruminant's Feed Resources. 25-29 Sept., pp: 119-130. Acad. Sci. Res. Technol., Cairo.

Abdelhamid, A.M.; Bassuny, S.M.; Abd El-Aziz, A.A. and Ibrahim, M.Y.S.A (2009a). Evaluation of biological treatments for agricultural by-products in ruminants feeding. I- Labouratorial study. J. Agric. Sci. Mansoura Univ., 34: $6227-6237$.

Abdelhamid, A.M.; Bassuny, S.M.; Abd El-Aziz, A.A. and Ibrahim, M.Y.S.A. (2009b). Evaluation of biological treatments for agricultural by-products 
in ruminants feeding. II- Digestibility study. J. Agric. Sci., Mansoura Univ., 34: 6239 - 6250 .

Abdelhamid, A.M.; Bassuny, S.M., Abd El-Aziz, A.A. and Ibrahim, M.Y.S.A. (2009c). Evaluation of biological treatments for agricultural by-products in ruminants feeding. III- Growth of lambs. J. Agric. Sci., Mansoura Univ., 34: 6251-6259.

Abdelhamid, A.M.; El-Shinnawy, M.M.; Aboul-Ela, M.B.; Dorra, T.M. and ElShiekh, M.M.H. (1991a). Effect of feeding dairy cattle on nonprotein nitrogen. I- On livebody weight and blood picture of the heifers during gestation period. J. Agric. Sci., Mansoura Univ., 16: 739 - 752.

Abdelhamid, A.M.; El-Shinnawy, M.M. and El-Emam, G.I.I. (1991b). Subsidizing rice straw with urea for partial substitution of concentrate feed mixture in fattening diets of crossbred calves. J. Agric. Sci., Mansoura Univ., 16: $1511-1523$.

Abdelhamid, A.M.; Faued. A.M., Ghanem, A.Z. and Helal, H.G. (2006). Studies on biological treatment of salt plants. 1- Feed evaluation by smll ruminants. J. Agric. Sci. Mansoura Univ., 31: $627-640$.

Abdelhamid, A.M.; Fayed, A.M., Ghanem, A.Z. and Helal, H.G. (2007). Studies on biological treatment of salt plants. II- Fattening trial. J. Agric. Sci., Mansoura Univ., 32: 151 - 165 (Ovine Technical Articles, engormix. Com., 2007, 12 p.).

Abdelhamid, A. M.; Ghanem, G. H. A., Aiad, A. M. and Matari, R. I. M. (2009d). Evaluating the possibility of recycling banana waste as a feed for ruminants. I- Chemical composition, rumen-liquor parameters, digestibility coefficients, and feeing values by lambs. J. Agric. Sci. Mansoura Univ., 34(11): 10451 - 1010467

A.O.A.C. (1980). Official methods of analysis (13 th edn). Association of official analytical chemists, Washignton, DC, USA.

A.O.A.C. (1990). Official methods of analysis (15 th edn). Association of official analytical chemists, Washignton, DC, USA.

Bendary, M.M.; Ghanem, G.H.A. and Gaafar, H.M.A. (2006). Utilization of rice straw for feeding ruminants: 2- Productive performance of lactating buffaloes fed rice straw silage. J. Agric. Sci. Mansoura Univ., 31: 5025 -5038 .

Douman, B.T.; Waston, W.A. and Homer, G.B. (1971). Albumin standards and the measurement of serum albumin with bromo-cresol green. Clinica chemical Acta, 31: 87 - 90.

Duncan, D.B. (1955). Multiple range and multiple Ftest-Biomtrics - 11: 1.

El-Ashry, M.A., Kholif, A.M., Fadel, M., El-Alamy, H.A., El-Sayed, H.M. and Kholif, S.M. (2003). Effect of biological treatments on chemical composition and in vitro and in vivo digestibilites of poor quality roughages. Egyptian J. Nutr. \& Feeds, 6: 113-126.

El-Sherif, Kh.; Tag El-Din, T.H., Abo Egla, E.H. and Abd El-Khalik, H. (2008). Performance of growing male rabbits fed diets containing banana leaves and yeast culture. Egypt. J. of Rabbit Sci., 18(2): 83 - 98.

Geoffroy, F.; Fabert, V.; Calif, E., Saminadin, G. and Vard. H. (1978). Leaves and stems of bananas as a source of forage, 1 - Availability and feeding value. (NAR, 50: 3291).

Gerona, G.R., Sanchez, S.L., Pasas, O.B., Anduyan, G.A.P., Jaya, A.F. and Barrientos, C.G. (1986). Utilization of banana plant residue by ruminant. (AB. Abst. Publ. Data).

Giorgio, J.D. (1974). Creatinin estimation: Clinical chemistry principles and techniques. Henry et al., eds., 242 - 543 Harper and Row, Hagerstown. 
Hassan, A.A.; Yacout, M.H.M.; Mohsen, M.K.; Bassiouni, M.I. and Abd El-All, M. (2005). Banana waste (Musa acuminata L.) Silage treated biologically or with urea for Dairy cows feeding. Egyptian J. Nutrition and feeds 8(1) Special Issue: $49-61$.

Ibrahim, M.A.; Holmann, F.; Hernandez, M. and Camero, A. (2000). Contribution of Erythrina protein banks and rejected bananas for improving cattle production in the humid tropics. Agroforestry systems; 49: 245.

Kholif, A.M., El-Alamy, H.A.; El-Ashry, M.A., El-Sayed, H.M., Fodel, M. and Kholif, S.M. (2001). Biological treatments of banana wastes lactating Goats Feeding. Egyptian J. Nutrition and feeds (2001) 4(Special Issue): 43

King, P.R.N. and King, D.M. (1959). Colourmetric determination of alkaline phosphatase activity. J. Clin. Path. 7: $322-329$

Mashour, W.; Riad, M. and Labib, E. (2002). Use of useful microorganisms in agriculture. Proc. Regional Workshop on: E.M. Uses and Agricultural Wastes Recycling. Cairo, 27 - 28 March, pp: 3-24.

Mohamed, I.M.E. (2001). Effect of mechanical, chemical and/or biological treatment of roughages on ruminal activity. Ph.D. Thesis, Fac. Agric., Cairo Univ., Egypt.

Mohsen, M.K.; Bassuni, M.I.; Yacout, M.H. and Mahmoud, M.A.M. (2006). Nutritional studies on the use of banana waste silage in feeding lactating cows. J. Agric. Res. Tanta Univ., 32(3): 2006.

NRC (1985). Nutrient requirements of sheep. Pp. 54 - 73. National Academy Press. Washington, DC.

Reitman, S. and Frankel, S. (1957). Colorimetric GOT and GPT Transaminases determination. Amer. J. Clin-Path., 28: $57-63$.

Rode, L.M., Yang, W.Z. and Beauchemin, K.A. (1999). Fibrolytic enzyme supplements for dairy cows in early lactation. J. Dairy Sci., 82: 2121 2126.

Shoukry, M.M.; El-Bedawy, T.M., Gihad, H.A., Ali, H.M., Salman, F.M. and ElKady, R.I. (1999). Utilization of banana wastes as hay and silage by sheep and goats. Egyptian J. Nutrition and Feeds, 2: $199-221$.

SPSS (2004). Statistical package for the Social Sciences. Release: 13. SPSS INC, Chicago, USA.

Talke, H. and Schubert, G.E. (1965). Enzymatic urea determination in serum and plasma. Klin. Wochenschr, 43: $174-175$.

Viswanathan, R., Kadirvel, R. and Chandrasederson, D. (1989). Nutritive value of banana stalk (Musa converdisia) as a feed for sheep. Animal Feed Science and Technology, 22: 127.

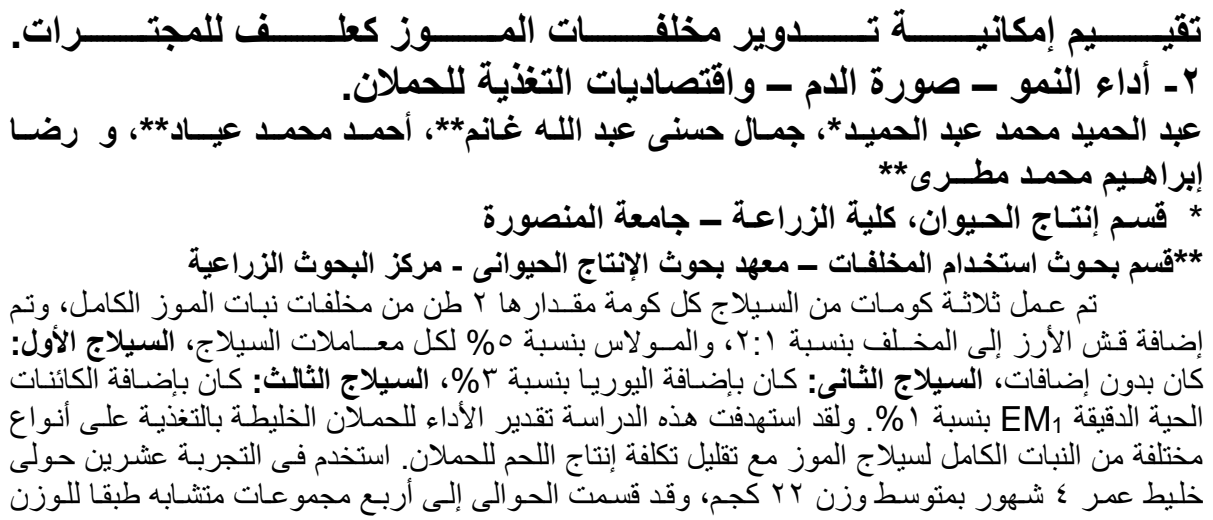


و ذللك لدر اسة معدل استهلاك الغذاء من المادة الجافة ـ معدل النمو اليومى ـ معدل التحويل الغذائى ـ و التكلفة

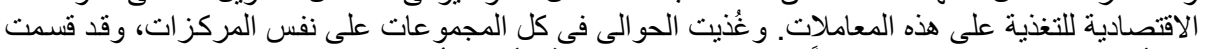

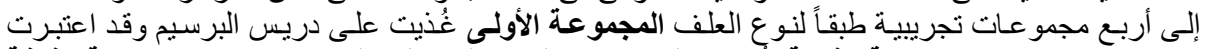

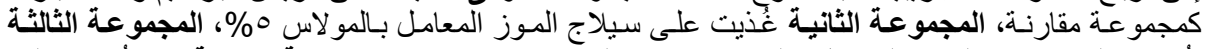

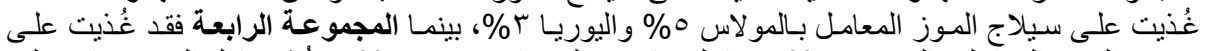

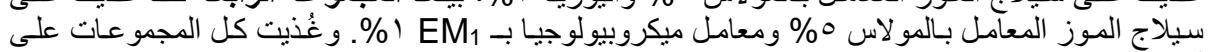

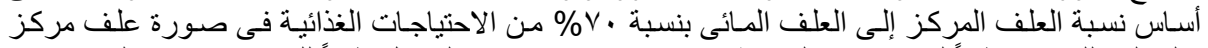

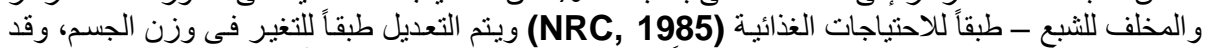

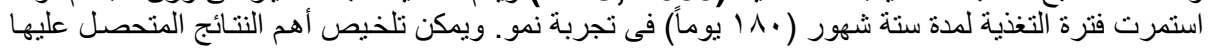

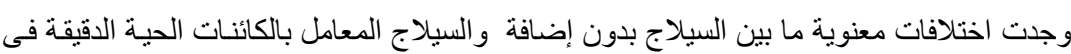
فيما يلى:- (انترن فترة

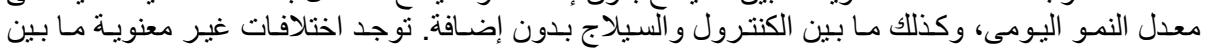

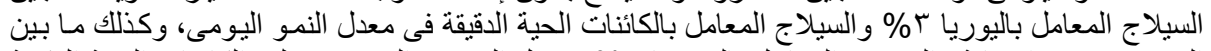

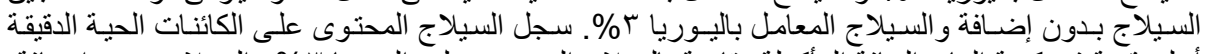

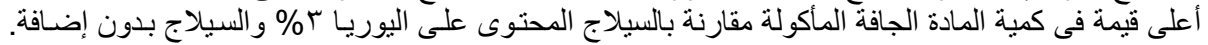

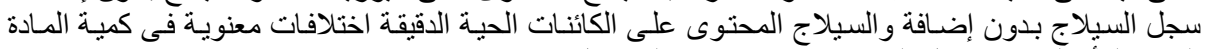

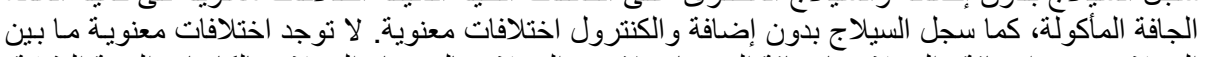

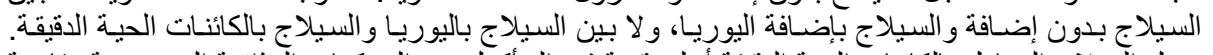

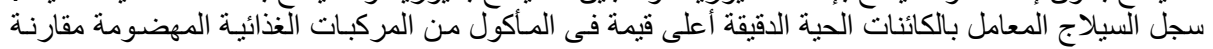

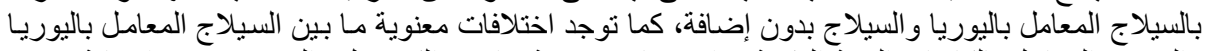

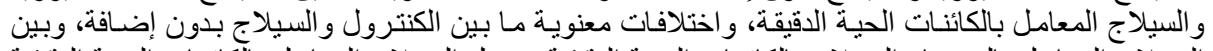

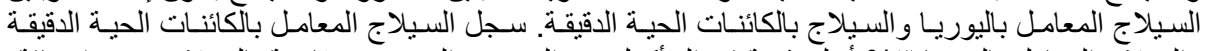

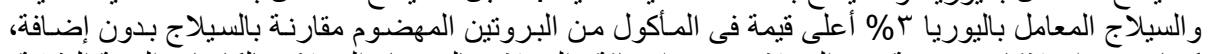

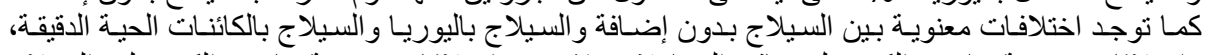

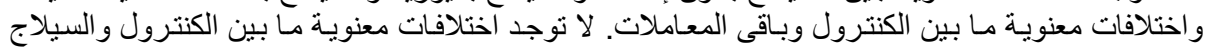

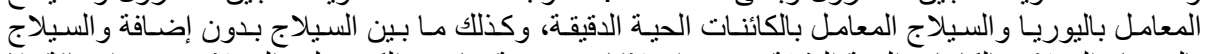

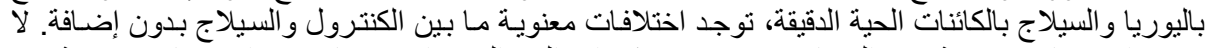

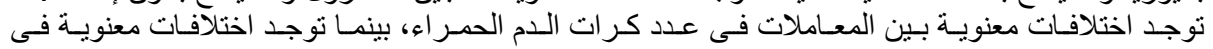

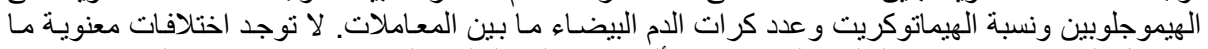

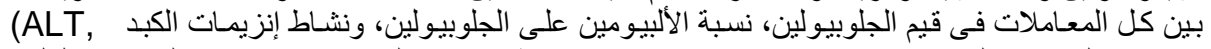

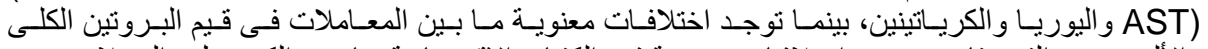

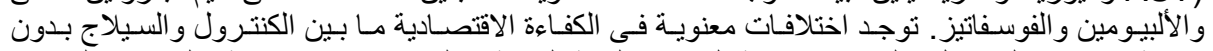

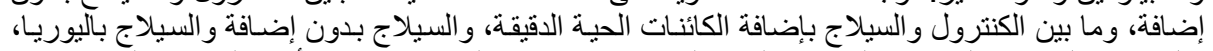

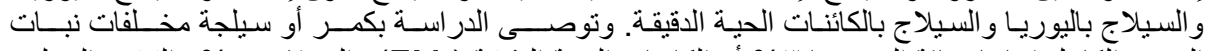

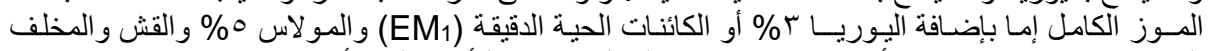

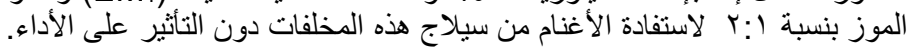

كلية الزراعه - جامعة المنصوره معهز بحوث الانتاج الحيوانى
قام بتحكيم البحث

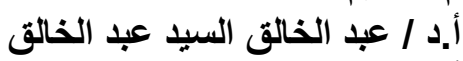
أ.د / أبهيره مصطفى كامل الفيد 